\title{
Characterization of three invading aquatic plants in Burkina Faso and their possible use for crop production
}

\author{
Ouola TRAORE $^{1 *}$, Karim TRAORE $^{1}$ and Adiza YAYE ${ }^{2}$ \\ ${ }^{1}$ Institut de l'Environnement et de Recherches Agricoles (INERA), Station de Farako-Bâ 01 BP 910 Bobo- \\ Dioulasso 01 Burkina Faso. Tel: +226209721 05, Fax: +22620970159 \\ ${ }^{2}$ Unité de Formation et de Recherche, Sciences de la Vie et de la Terre (UFR/SVT), \\ Université de Ouagadougou, Burkina Faso. \\ *Corresponding Author, E-mail: ouola.traore@coraf.org Tel: +226 209721 05, Fax: +226 20970159
}

\begin{abstract}
Crop production in the Sahel is limited by both nutrients and water availability. This study evaluated the possible use of three invading plants (Azolla pinnata, Ceratophyllum demersum and Typha australis) for crop production. For that, two pots experiments and a single on-farm experiment were carried in Farako-Bâ research center in Burkina Faso in 2005 and 2006. The treatments compared the effect of raw and composted substrates application on the fonio (Digitaria exilis, CVF 477) and the maize (Zea mays, FBH-34 SR) production. Both raw and composted substrates were analyzed for their nutrient content before being incorporated in the soil. The results showed that both substrates (composted and not) have higher phosphorus and nitrogen content for $C$. demersum compared to T. australis and A. pinnata. T. australis is a lignified substrate with a $\mathrm{C} / \mathrm{N}$ ratio of 55 and 26 , respectively for not and composted substrates. The composting process increased substrates $\mathrm{pH}$ of about a unit for A. pinnata and $C$. demersum and 4 units for T. australis. The fonio and the maize biomass production were not significantly different for substrates. The maize yield benefit was highest for $C$. demersum. The three aquatic invading plants represent a high potential for crop production in the Sahel. However, the long term effects of substrates are to be assessed.

(C) 2009 International Formulae Group. All rights reserved.
\end{abstract}

Keywords: Water, Sahel, aquatic invading plants, raw and composted substrate, yield benefit.

\section{INTRODUCTION}

Cotton is the main cash crop in Burkina Faso and represents the only source of income for many households. The extension of cotton cropping areas during the $80^{\text {th }}$ was followed by an increased use of chemical fertilizers and pesticides. This resulted in important crop yield increment but also in environment pollution (Toé et al., 2004). In fact, because of inadequate land protection these fertilizers and pesticides were transported in rivers by runoff. The later coupled with a global climate changes (mainly temperatures and rainfall) generated the spread of some aquatic invading plants which found favourable conditions to multiply and colonize large water lands.

Many aquatic plant species were recorded as invading plants in the tropical zone: Eichhornia crassipes, Chromolaena odorata, Pistia stratiotes, Salvinia molesta, Typha australis, Azolla pinnata, Ceratophyllum demersum. Some of these aquatic invading plants were studied (Roger and Reynaud, 1979; Sawadogo, 1986; Chapman and Margilus, 1998; Kabelma, 2005) but many of them as T. australis, $A$. pinnata or $C$. demersum have received little attention from scientists. These plants, 
although considered as invading plants, could represent important sources of nutrients for crops because they absorb important quantities of nutrients which are released when these plants die. The use of invading plants for crops production could be seen as a profitable way to fight these aquatic parasites. The main objective of the current study is to avoid the water land invasion by invading aquatic plants (in Burkina Faso through their recycling for crops production). We assume that the invading plants used as green manure or compost can ensure the production of most crops and the capacity of releasing nutrients to soil depends on the type and the form of application.

\section{MATERIAL AND METHODS \\ Site description}

The study was carried out in 2005 and 2006 in Farakoba research station, in the south-sudanian zone of Burkina Faso. The geographical coordinates of Farakoba research station are latitude $11^{\circ} 06^{\prime}$ North and longitude $4^{\circ} 20^{\prime}$ 'West. The climate is south-sudanian (Guinko, 1984) with annual average rainfall (1993-2003) of $997 \mathrm{~mm}$. The temperatures vary between 17 and $37{ }^{\circ} \mathrm{C}$ during the dry season (November-May) and between 10 and $32{ }^{\circ} \mathrm{C}$ during the wet season (June-October). The evapo-transpiration is $8.7 \mathrm{~mm}$ /day between January and March and $3.7 \mathrm{~mm}$ /day between July and September. The soils are ultisols (USDA soil classification) with low clay and organic matter content, which explains their low cation exchange capacity. The topsoil is sandy to sandy loam. The soils are slightly acidic and have a low nitrogen and phosphorus content (Bado, 2002).

\section{Aquatic invading plant sampling and composting}

The three aquatic plants were collected in the pond of hippopotamus of Balla in the south-sudanian zone of Burkina and the dam of Loumbila in the north-soudanian zone. A. pinnata and $C$. demersum were collected at the surface of water plan whereas $T$. australis was cut $5 \mathrm{~cm}$ above the ground. Part of the aquatic plants collected was composted during 30 days, using the semi anaerobic composting method. The method consisted of manual stirring up of the heap every 5 days followed by an abundant watering.

\section{Pots experiments}

The pots experiments started on October 10, 2005 and ended on January 5, 2006. The soil used in the pots was sampled in the research station. The chemical properties of the soil are presented in table 1.

Plastic pots of 5 liters were used for the pots experiments. Before being used, the soil was sieved at $2 \mathrm{~mm}$ and mixed to make it uniform. In each plastic pot, $4 \mathrm{~kg}$ of the soil were placed. The pots were then amended with substrates composted or not at the doses of 1.33 and $2.66 \mathrm{~g}$ of dry matter per pot. These doses are respectively equivalent to 1 and 2 tons of dry matter per hectare. The substrates were combined with mineral fertilizers. The mineral fertilizer was applied in the form of NPKSB (14-23-14-6) and of urea $(46 \% \mathrm{~N})$. The quantities of fertilizers applied per crop were done based on the recommendations from the extension office. The following doses of fertilizers were applied: for the maize $0.133 \mathrm{~g}$ of NPKSB and $0.133 \mathrm{~g}$ of urea per pot, corresponding to $100 \mathrm{~kg} / \mathrm{ha}$ of NPKSB and $100 \mathrm{~kg} / \mathrm{ha}$ of urea. For the fonio (Digitaria exilis, CVF 477), $0.13 \mathrm{~g}$ of NPKSB and urea $0.07 \mathrm{~g}$ were applied per pot which corresponds to $100 \mathrm{~kg} / \mathrm{ha}$ of NPKSB and 50 $\mathrm{kg} / \mathrm{ha}$ of urea. The NPKSB was applied at sowing and urea, 20 days after emergence. The treatments for the raw substrates are presented in table 2 .

For the composted substrates, 5 treatments were compared (Table 2). Only the composts of $A$. pinnata and $C$. demersum were tested. T. australis was not completely decomposed when the pot experiment started.

Table 1: Chemical properties of the soil used in the pots experiments.

\begin{tabular}{lc}
\hline Chemical properties & Average values \\
\hline Total C $(\%)$ & $0.29(0.05)^{*}$ \\
Total $\mathrm{N}(\%)$ & $0.03(0.004)$ \\
Organic matter $(\%)$ & $0.50(0.08)$ \\
Total P $(\mathrm{mg} / \mathrm{kg})$ & $84.3(10.9)$ \\
Available $\mathrm{P}(\mathrm{mg} / \mathrm{kg})$ & $3.55(0.79)$ \\
$\mathrm{C} / \mathrm{N}$ ratio & $8.60(0.74)$ \\
$\mathrm{pH}-$ water & $5.56(0.15)$ \\
pH-KCl & $4.30(0.17)$ \\
\hline * Values between brackets are standard deviations.
\end{tabular}


Table 2: Treatments compared in the pots experiments.

A: Not composted substrates.

\begin{tabular}{ll}
\hline Treatments & Definition \\
\hline Control & Recommended Mineral Fertilization $\left(\mathrm{MF}^{*}\right)$ \\
$\mathrm{Az} 1$ & Azolla pinnata $(1.33 \mathrm{~g} / \mathrm{pot})+\mathrm{MF}$ \\
$\mathrm{Az} 2$ & A. pinnata $(2.66 \mathrm{~g} / \mathrm{pot})+\mathrm{MF}$ \\
Cera 1 & Ceratophyllum demersum $(1.33 \mathrm{~g} / \mathrm{pot})+\mathrm{MF}$ \\
Cera 2 & C. demersum $(2.66 \mathrm{~g} / \mathrm{pot})+\mathrm{MF}$ \\
Typh 1 & Typha australis $(1.33 \mathrm{~g} / \mathrm{pot})+\mathrm{MF}$ \\
Typh 2 & T. australis $(2.66 \mathrm{~g} / \mathrm{pot})+\mathrm{MF}$ \\
\hline
\end{tabular}

B: Composted substrates.

\begin{tabular}{ll}
\hline Treatments & Definition \\
\hline Control & Recommended Mineral Fertilization $(\mathrm{MF})$ \\
Comp Az 1 & Compost of $A$. pinnata $(1.33 \mathrm{~g} / \mathrm{pot})+\mathrm{MF}$ \\
Comp Az 2 & Compost of A. pinnata $(2.66 \mathrm{~g} / \mathrm{pot})+\mathrm{MF}$ \\
Comp Cera 1 & Compost of $C$. demersum $(1.33 \mathrm{~g} / \mathrm{pot})+\mathrm{MF}$ \\
Comp Cera 2 & Compost of $C$. demersum $(2.66 \mathrm{~g} / \mathrm{pot})+\mathrm{MF}$ \\
\hline
\end{tabular}

MF*: Mineral Fertilization corresponds to $0.133 \mathrm{~g} /$ pot of complex fertilizer NPKSB and $0.133 \mathrm{~g} / \mathrm{pot}$ of urea with maize and $0.13 \mathrm{~g} /$ pot of NPKSB and $0.07 \mathrm{~g} /$ pot of urea with "fonio" (Digitaria exilis, CVF 477).

The pots were randomly ranged in 4 blocks corresponding to the replications. The number of experimental units was 56 pots (7 treatments $\times 4$ replications $\times 2$ crops) for the not composted substrates and 40 pots (5 treatments $\times 4$ replications $\times 2$ crops) for the composted ones.

Two crops were used as vegetal material for the pots experiments: maize and fonio. The maize variety (Zea mays, FBH-34 SR) had a growth cycle (sowing-maturity) of 97 days with a potential grain yield of 6500 $\mathrm{kg} / \mathrm{ha}$ and the fonio (Digitaria exilis, CVF 477) had a growth cycle of 105 days with potential grain yield of $4000 \mathrm{~kg} / \mathrm{ha}$. All the pots were watered at field capacity during 24 hours before the crops were sown. The crops were sown at density of 25 seeds per pot for the fonio and 6 seeds per pot for the maize. After emergence, the number of plants was reduced to 2 plants per pot for the maize and 10 plants per pot for the fonio. The water status of the pots was maintained at field capacity by daily watering

\section{On-farm experiment}

The on-farm experiment was also carried out in Farako-Bâ research station on a sandy acidic soil in 2006. The characteristics of the soils are summarized in table 3.

The experiment design used in the field was a block fisher. The size of experimental unit was $25 \mathrm{~m}^{2}(5 \mathrm{~m} \times 5 \mathrm{~m})$. The distance between the experimental units was $0.5 \mathrm{~m}$ while the blocks were separated by alleys of 2 $\mathrm{m}$. In the field experiment, only the composted substrates were used. The treatments structure consisted of composts of substrates and mineral fertilizers. The four (4) following treatments were tested in the field:

1) Mineral fertilizer (MF);

2) Compost of $A$. pinnata (2 t/ha) $+\mathrm{MF}$;

3) Compost of $C$. demersum (2t/ha) $+\mathrm{MF}$;

4) Compost of $T$. australis (2 t/ha) + MF.

The composted substrates were incorporated in the soil during land preparation at $10 \mathrm{~cm}$ depth. The treatments were randomly applied in 4 blocks corresponding to replications. The vegetal material used was maize. The planting density was $80 \mathrm{~cm} \times 40 \mathrm{~cm}$. Three maize seeds were sown per seed hole. The number of plants per hole was reduced to 2 plants 15 days after emergence. The maize was fertilized with 100 $\mathrm{kg} / \mathrm{ha}$ of NPKSB and $100 \mathrm{~kg} / \mathrm{ha}$ of urea. The NPKSB was applied at sowing and urea, 20 days after emergence. 
Table 3: Physical and chemical characteristics of Farako-Bâ soils. Field experiment 2006.

\begin{tabular}{lc}
\hline Soil properties & $\begin{array}{c}\text { Average } \\
\text { value }\end{array}$ \\
\hline Clay (\%) & 7 \\
Sand (\%) & 74 \\
Silt $(\%)$ & 19 \\
Total carbon $(\%)$ & 1.1 \\
Organic matter $(\%)$ & 0.61 \\
Total N (mg/kg) & 409 \\
Total P $(\mathrm{mg} / \mathrm{kg})$ & 69.8 \\
Total K $(\mathrm{mg} / \mathrm{kg})$ & 531 \\
P Bray I $(\mathrm{mg} / \mathrm{kg})$ & 5.6 \\
Exchangeable Ca $\left(\mathrm{Cmol}^{+} / \mathrm{kg}\right.$ soil) & 1.08 \\
Exchangeable K $\left(\mathrm{Cmol}^{+} / \mathrm{kg}\right.$ soil) & 0.02 \\
Exchangeable Mg $\left(\mathrm{Cmol}^{+} / \mathrm{kg}\right.$ soil) & 0.46 \\
CEC $(\mathrm{Cmol} / \mathrm{g} \mathrm{soil)}$ & 1.82 \\
Exchange acidity $\left(\mathrm{Cmol}^{+} / \mathrm{g}\right.$ soil) & 0.08 \\
Bases Saturation $(\%)$ & 96 \\
pH-water & 6.5 \\
pH-KCl & 5.6 \\
\hline
\end{tabular}

\section{Data collection}

In the pot experiment, total production of crops was evaluated. For that, the above and the below ground biomass were harvested, sun dried and oven dried at $60{ }^{\circ} \mathrm{C}$ during 72 hours. For the fonio, the biomass was collected at two periods: 31 days after sowing and 70 days after sowing. For the maize, the biomass was collected only at 50 days after sowing. For the field experiment, the growth and development of the maize were regularly assessed by measuring the height of the plants. The yields components were determined at maturity.

\section{Laboratory analysis}

The chemical properties of the substrates were determined in Farako-Bâ soilplant-water laboratory in Burkina Faso. The samples were sun- and oven-dried, ground and sieved at $2 \mathrm{~mm}$. The $\mathrm{pH}$ water of the samples was determined using a pH-meter (WTW 521) in a suspension compost-water at ratio $1 / 2.5$. Total $\mathrm{C}, \mathrm{N}$ and $\mathrm{P}$ were respectively determined using the methods of WalkeyBlack (Black et al., 1965; Novosamsky et al., 1983; Okalebo, 2002). Total K was determined by spectrophotometry.

\section{Data analysis}

All data collected were computed, using Excel package and the analysis of variance performed with GenStat (2005). The means were separated using the least significant difference (LSD) at probability of $5 \%$.

\section{RESULTS}

Chemical characteristics of substrates

The chemical characteristics of substrates (composted and not composted) are presented in table 4 . The results show that the raw substrates (not composted one) are characterized by their high organic matter content. The data show also comparable organic matter content for A. pinnata and $T$. australis but $15 \%$ higher compared to $C$. demersum (Table 4). Organic matter content decreased with composting. The level of decrease was more important for $C$. demersum (23\%) compared to A. pinnata $(10 \%)$ and $T$. australis $(<5 \%)$.

The data show significant differences between substrates for their $\mathrm{N}$ content and the following order was observed: $C$. demersum > A. pinnata $>T$. australis. Oppositely to the organic matter content, the composting process increased $\mathrm{N}$ content. The increment was highest for T. australis (188\%) compared to $C$. demersum (40\%) and A. pinnata (18\%) although the absolute value was lowest for $T$. australis (Table 4).

The $\mathrm{C} / \mathrm{N}$ ratio was highest for $T$. australis and was in the order T. australis $>A$. pinnata $>C$. demersum. The composting decreased $\mathrm{C} / \mathrm{N}$ ratio. The level of decrease was more important for T. australis compared to the other 2 substrates. The higher $\mathrm{C} / \mathrm{N}$ ratio found in T. australis is in concordance with the $\mathrm{C}$ and $\mathrm{N}$ content of that substrate. The phosphorus (P) content of substrates was highest for $C$. demersum compared to $T$. australis and $A$. pinnata. The lowest total phosphorus was found in $A$. pinnata. The composting process increased total $\mathrm{P}$ content. The increment was comparable for $T$. australis and $C$. demersum but higher compared to $A$. pinnata. Data showed that substrates total $\mathrm{K}$ was comparable for $T$. australis and $C$. demersum but higher compared to $A$. pinnata. The composting process had a low impact on $\mathrm{K}$ concentration (Table 4). The $\mathrm{pH}$ of substrates is alkaline for $C$. demersum and neutral for T. australis and A. pinnata. The substrates $\mathrm{pH}$ increased with composting. The $\mathrm{pH}$ increased of about three 
units for $T$. australis and $C$. demersum and one unit for A. pinnata.

\section{Contribution of substrates to crops biomass production}

\section{Effect of raw substrates}

The direct application of raw substrates show no significant effect on below and above ground biomass production $(\mathrm{P}>0.05)$. Similar results were found for both fonio and maize (Table 5).

However, for fonio (Digitaria exilis, CVF 477), there was tendencies for $C$. demersum to produce more below and above ground biomass compared to the two other substrates. For the maize biomass production no significant difference was observed between treatments (table 5). In total there was no clear pattern with the application of the raw substrates. However, the ratio above/below ground biomass is crop dependent. The ratio was higher for the fonio $(1.8<$ ratio < 3.43$)$ compared to maize $(0.82<$ ratio $<1.17)$.

\section{Effect of composted substrates}

The production of biomass differed for treatments and crops (Table 5). For the fonio, the above ground biomass production significantly differed with the type of compost. The lowest biomass production was obtained with the lowest dose of A. pinnata (1 t/ha) while the highest production was found with the compost of $C$. demersum. The below ground biomass production of the fonio was not significantly different for the nature and the dose of compost. For the maize, the biomass production was not statistically different, however, results showed an absolute value higher above and below ground biomass, following the application of the compost of substrates.

Effect of composts on maize production (onfarm experiment)

The results showed that crop production was higher with compost application compared to mineral fertilizer application except for A. pinnata (Table 6). The maize grain yield was highest in absolute value basis when fertilized with the compost of $C$. demersum. The numbers of full ears was higher with the compost of $C$. demersum compared to the ones of the two other composts derived from $T$. australis and $A$. pinnata. The results showed a significant proportion of empty ears for the compost of $T$. australis. The 1000 seed weights and grain yields were higher with the compost of $C$. demersum, compared to the composts of the other substrates. The best straw yield was obtained with the compost of $T$. australis. The harvest index was lower with the compost of $T$. australis (0.31) compared to the compost of A. pinnata (0.36) and C. demersum (0.41).

\section{DISCUSSION}

The $\mathrm{C} / \mathrm{N}$ ratio of $T$. australis is out the range of 25-35 considered as optimal $\mathrm{C} / \mathrm{N}$ ratio values to start a good decomposition process (Gotaas, 1959; Mustin, 1987; Amir, 2005). The two other substrates have lower $\mathrm{C} / \mathrm{N}$ ratio and should potentially decompose faster. The compost of $C$. demersum constitutes an ideal substrate for improving land productivity in Burkina where soils are deficient in $\mathrm{N}$ and $\mathrm{P}$ (Traoré et al., 2007; Bationo et al., 1998). The $\mathrm{C} / \mathrm{N}$ ratio of $T$. australis decreased of about $50 \%$ during the composting process. However, the final ratio of 26 is considered still too high for good decomposition when incorporated in the soil. The compost of $T$. australis could represent a long-term solution for the improvement of soil organic matter content in Burkina. The application of composted substrates to acid soils affected soils $\mathrm{pH}$, allowing more nutrients availability as reported by previous studies (Traoré and Stroosnijder, 2005). No real effect was observed with the raw substrate application. There was tendency for negative impact of the raw substrate application. This is probably due to $\mathrm{N}$ sequestration by micro-organisms for their metabolism during the early stages of the crops. The results show higher biomass production with compost application and the yields were highest with the most easily degradable substrate.

Pedneault (1994) explained these results by the fact that the humus acts directly on the physiology of the plants by reducing the transpiration and the consumption of water, increasing roots breathing and photosynthesis, improving the effectiveness of internal metabolisms, stimulating the formation and the growth of the roots and stems and increasing the yield and the resistance of plants. So the organic matter application has both physiological and 
Table 4: Chemical characteristics of the three substrates.

\begin{tabular}{lcccccc}
\hline \multirow{2}{*}{$\begin{array}{l}\text { Substrate } \\
\text { characteristics }\end{array}$} & \multicolumn{2}{c}{ Azolla pinnata } & \multicolumn{2}{c}{ Ceratophyllum demersum } & \multicolumn{2}{c}{ Typha australis } \\
\cline { 2 - 7 } & $\begin{array}{c}\text { Not } \\
\text { composted }\end{array}$ & Composted & $\begin{array}{c}\text { Not } \\
\text { composted }\end{array}$ & Composted & $\begin{array}{c}\text { Not } \\
\text { composted }\end{array}$ & Composted \\
\hline Organic C (\%) & $47.2 \pm 7.00^{\#}$ & $42.3 \pm 3.21$ & $40.8 \pm 2.57$ & $31.18 \pm 3.54$ & $50.7 \pm 4.03$ & $45.5 \pm 5.06$ \\
Organic matter (\%) & $82.0 \pm 4.00$ & $71.9 \pm 3.59$ & $73.2 \pm 1.41$ & $55.6 \pm 10.5$ & $86.50 \pm 6.5$ & $83.7 \pm 11.5$ \\
N (g/kg DM $)$ & $16.9 \pm 7.00$ & $20.5 \pm 1.50$ & $19.8 \pm 4.41$ & $27.7 \pm 2.05$ & $9.09 \pm 1.10$ & $16.9 \pm 1.68$ \\
Total P (mg/kg DM) & $789.8 \pm 13.1$ & $932.9 \pm 76.5$ & $4467.0 \pm 351.3$ & $6304.6 \pm 200.1$ & $904.6 \pm 50.6$ & $2589.0 \pm 356.5$ \\
Total K (\%) & $2.55 \pm 1.29$ & $1.82 \pm 0.30$ & $4.47 \pm 2.00$ & $6.37 \pm 0.66$ & $3.4 \pm 2.01$ & $2.34 \pm 0.45$ \\
C/N & $28.5 \pm 2.5$ & $20.6 \pm 2.40$ & $19.5 \pm 5.08$ & $11.8 \pm 3.25$ & $55.2 \pm 6.15$ & $26.1 \pm 6.00$ \\
pH water & $6.44 \pm 0.80$ & $7.16 \pm 0.65$ & $9.37 \pm 0.85$ & $10.2 \pm 0.75$ & $6.08 \pm 0.21$ & $9.88 \pm 0.58$ \\
\hline \multicolumn{2}{c}{ Each value represents the average of three measurements, DM ${ }^{*}$ Dry matter, ${ }^{\#}:$ standard deviation. }
\end{tabular}

Table 5: Effect of substrates on crops biomass production. Pot experiment 2006.

A: Not composted substrates.

\begin{tabular}{lcccc}
\hline \multirow{2}{*}{ Treatments } & \multicolumn{2}{c}{$\begin{array}{c}\text { Fonio } \\
\text { (Digitaria exilis, CVF 477) }\end{array}$} & \multicolumn{2}{c}{$\begin{array}{c}\text { Maize } \\
\text { (Zea mays, FBH-34 SR) }\end{array}$} \\
\cline { 2 - 5 } & \multicolumn{2}{c}{ Above ground Below ground } & Above ground Below ground \\
\cline { 2 - 5 } Control & \multicolumn{2}{c}{ (g DM/pot) } & \multicolumn{2}{c}{ (g DM/pot) } \\
Az 1 & 7.49 & 3.35 & 76 & 5.84 \\
Az 2 & 8.48 & 2.99 & 7.13 & 6.58 \\
Cera 1 & 10.27 & 4.82 & 6.95 & 7.11 \\
Cera 2 & 12.54 & 4.69 & 6.85 & 7.11 \\
Typh 1 & 8.03 & 3.69 & 7.14 & 8.66 \\
Typh 2 & 7.20 & 2.46 & 6.75 & 6.63 \\
\hline Probability & $\mathbf{0 . 2 3}$ & $\mathbf{0 . 3 5}$ & $\mathbf{0 . 8 2}$ & $\mathbf{0 . 2 2}$ \\
LSD & $\mathbf{4 . 9 9}$ & $\mathbf{3 . 0 1}$ & $\mathbf{2 . 1 1}$ & $\mathbf{2 . 3 6}$ \\
\hline
\end{tabular}

B: Composted substrates.

Fonio Maize

Treatments Above ground Below ground Above ground Below ground

\begin{tabular}{lllll} 
& (g DM/pot) & \multicolumn{3}{c}{ (g DM/pot) } \\
\hline Control & 6.79 & 3.29 & 3.77 & 4.54 \\
Comp Az 1 & 4.70 & 1.80 & 5.00 & 5.73 \\
Comp Az 2 & 7.09 & 2.74 & 4.03 & 4.43 \\
Comp Cera 1 & 7.41 & 3.67 & 4.04 & 4.61 \\
Comp Cera 2 & 6.96 & 3.18 & 4.78 & 5.68 \\
\hline Probability & $\mathbf{0 . 0 2}$ & $\mathbf{0 . 1 4}$ & $\mathbf{0 . 5 7}$ & $\mathbf{0 . 5 4}$ \\
LSD & $\mathbf{1 . 5 8}$ & $\mathbf{1 . 5 3}$ & $\mathbf{1 . 8 7}$ & $\mathbf{2 . 2 3}$ \\
\hline
\end{tabular}

DM: Dry matter 
Table 6: Effect of the composts on maize plants height and yield components. Field experiment 2006.

\begin{tabular}{lccccccc}
\hline Treatments & $\begin{array}{c}\text { Height } \\
\text { seedlings } \\
\text { (cm) }\end{array}$ & $\begin{array}{c}\text { Number } \\
\text { of full } \\
\text { ears/ha }\end{array}$ & $\begin{array}{c}\text { Number of } \\
\text { empty } \\
\text { ears/ha }\end{array}$ & $\begin{array}{c}\text { Weight of } \\
\mathbf{1 0 0 0} \\
\text { Seeds }(\mathbf{g})\end{array}$ & $\begin{array}{c}\text { Ears } \\
\text { yield } \\
\text { (kg/ha) }\end{array}$ & $\begin{array}{c}\text { grain } \\
\text { yield } \\
\text { (kg/ha) }\end{array}$ & $\begin{array}{c}\text { Straw } \\
\text { yield } \\
\text { (kg/ha) }\end{array}$ \\
\hline $\begin{array}{l}\text { Mineral Fertilization } \\
\text { (MF) }: 100 \mathrm{~kg} / \mathrm{ha}\end{array}$ & 174.4 & 47433 & 12277 & 214.1 & 2637 & 2130 & 3502 \\
$\begin{array}{l}\text { NPKSB + 100 kg/ha urea) } \\
\text { Compost of Azolla pinnata }\end{array}$ & 187.7 & 47433 & 13393 & 224.2 & 2425 & 1981 & 3557 \\
$\begin{array}{l}\text { (2t/ha) + MF } \\
\text { Compost of Ceratophyllum } \\
\text { demersum (2t/ha) }\end{array}$ & 191.0 & 52735 & 8929 & 237.2 & 3118 & 2563 & 3697 \\
$\begin{array}{l}\text { Compost of Typha australis } \\
\text { (2t/ha) + MF }\end{array}$ & 183.5 & 40458 & 13951 & 229.5 & 2864 & 2357 & 3934 \\
\hline $\begin{array}{l}\text { Probability } \\
\text { LSD }\end{array}$ & $\mathbf{0 . 7 7}$ & $\mathbf{0 . 4 6}$ & $\mathbf{0 . 7 0}$ & $\mathbf{0 . 5 4}$ & $\mathbf{0 . 5 4}$ & $\mathbf{0 . 5 2}$ & $\mathbf{0 . 8 8}$ \\
\hline & $\mathbf{3 7 . 7}$ & $\mathbf{1 6 6 0 0 . 0}$ & $\mathbf{1 0 2 5 1 . 0}$ & $\mathbf{3 5 . 3}$ & $\mathbf{1 0 8 1 . 7}$ & $\mathbf{9 1 2 . 7}$ & $\mathbf{1 3 3 6 . 7}$ \\
\hline
\end{tabular}

biological meaning. The application of the double dose of substrate allows only a small profit in term of biomass production and does not seem to be economically profitable.

\section{Conclusion}

This study showed the potentialities offered by the three aquatic invading plants. The results show that the three studied plants contain considerable amount of organic matter and nutrients. Among the three invading plants, Ceratophyllum demersum either used as green manure or as compost gives the best results. Typha australis is characterized especially by a high $\mathrm{C} / \mathrm{N}$ ratio. This substrate could be used as important source of organic matter. The effect of the various substrates composted or not, on the production of crops showed real tendencies. The compost of $C$. demersum is probably the most effective because of its higher nutrients contents. The maize grains yields are in general higher for the composts, compared to that of the only mineral fertilization. The effect of the composts seems to be significant on harvest index. The aquatic plants can be used for agricultural production. These plants could leave the position of parasitic plants and become useful plants for agricultural production. However it's necessary to evaluate the effect of these composts on crops seeds and grain nutrients content. Moreover, the composts must be tested on the other crops under different agro-ecological conditions of the country. In the context of an increasing chemical fertilizers price, the use of aquatic plants is a solution for the sustainability of cropping systems.

\section{REFERENCES}

Amir S. 2005. Contribution à la valorisation de boues de stations d'épuration par compostage : devenir des micropolluants métalliques et organiques et bilan humique du compost. Thèse de doctorat $3^{\text {ème }}$ cycle, Institut National Polytechnique de Toulouse, $341 \mathrm{p}$.

Bado BV. 2002. Rôle des légumineuses sur la fertilité des sols ferrugineux tropicaux des zones guinéennes et soudaniennes du Burkina Faso. Thèse de $\mathrm{PhD}$, Département des sols et Environnement, Université Laval, 145 p.

Bationo A, Lompo F, Koala S. 1998: Research on nutrient flows and balances in West Africa: state of the art. Agriculture, Ecosystems and Environment, 71: 19-35.

Black CA, Evans DD, Ensmincer DE, White JL, Clarck FA, Diraver RC. 1965. Methods of soil analysis II. Am. Soc. Agron. Inc.: 1367-1375.

Chapman, MJ, Margilus L. 1998. Morphogenesis by symbiogenesis. Inter. J. Microbiol., 1: 319-326.

GenStat Release 8. 2005. Lawes Agricultural Trust (Rothmsted Experimental Station).

Gotaas HB. 1959. Compostage et Assainissement. OMS : Genève ; $210 \mathrm{p}$.

Guinko S. 1984. Végétation de la HauteVolta. Thèse de doctorat, Sciences 
naturelles, Université de Bordeaux III. 2 tomes, 394 p. + annexes.

Kabelma B. 2005. Application de l'Azolla comme biofertilisant pour la culture du riz. Proceedings of the Forum on Biological Nitrogen Fixation (BNF), Session 2: Status of BNF research and application in Africa. International Organisation of Biotechnology and Bioengineering (IOBB).

Mustin M. 1987. Le Compostage: Gestion de la Matière Organique. Edn François Dubusc : Paris (FR); 954p.

Novosamsky I, Houba VJG, Eck va R, Vark va W. 1983. A novel digestion technique for multi-element plant analysis. Communications in Soil and Plant Analysis, 14: 239-249.

Okalebo JR. 2002. Laboratory Methods of Soil and Working and Plant Analysis: A Working Manuel ( $2^{\text {nd }}$ Edn); 128 p.

Pedneault A. 1994. Les effets du compost sur les plantes. Québec Vert : 18-20.

Roger PA, Reynaud PA. 1979. Premières données sur l'écologie d'Azolla africana en zone sahélienne (Sénégal). Ecologia Plantarum, 14(1): 75-84.

Sawadogo JA. 1986. Azolla: synthèse des résultats de recherche de 1982 à 1986. INERA, Burkina Faso, 24 p.

Toé AM, Domo Y, Héma SAO, Guissou IP. 2004. Les pesticides au Sahel. Utilisation, Impact et Alternatives, Burkina Faso : Épidémiologie des intoxications aux pesticides et activité cholinestérasique sérique chez les producteurs de coton de la zone cotonnière de la Boucle du Mouhoun. Etudes et Recherches Sahéliennes, 4-5: 39-48.

Traoré K, Stroosnijder L. 2005. Sorghum quality, organic matter amendments and health; farmers' perception in Burkina Faso, West Africa. Ecology of Food and Nutrition, 44: 225-245.

Traoré O, Traoré K, Bado BV, Lompo DJP. 2007. Crop rotation and soil amendments: impacts on cotton and maize production in a cotton based system in western Burkina Faso. Int. J. Biol. Chem. Sci., 1(2): 143-150. 